\title{
Wnt signalling in pituitary development and tumorigenesis
}

\author{
T J G Chambers, A Giles, G Brabant ${ }^{1}$ and J R E Davis
}

Endocrinology and Diabetes Group, Faculty of Medical and Human Sciences, Centre for Endocrinology and Diabetes, Institute of Human Development, University of Manchester, AV Hill Building, Oxford Road, Manchester M13 9PT, UK 'Experimental and Clinical Endocrinology, Med Clinic I, University of Lübeck, Lübeck, Germany

Correspondence should be addressed to J R E Davis Email julian.davis@ manchester.ac.uk

\begin{abstract}
Wnt signalling is activated in both pituitary organogenesis and its mature function. Wnt ligands and Wnt signalling pathways are critical for the regulation of the formation of the pituitary. In the mature pituitary, Wnt signalling pathways control cell activity and may stimulate cell proliferation in both physiological and pathological processes. This review compares Wnt signalling pathways active in the developing and mature pituitary and explores how this gives us further insight into the development of pituitary adenomas.
\end{abstract}

\section{The pituitary}

The anterior pituitary produces peptide hormones under the control of feedback from hormones secreted by the hypothalamus and the peripheral endocrine glands. This is enabled by five different populations of cells: corticotrophs which make ACTH; gonadotrophs which secrete FSH and LH; somatotrophs making GH; thyrotrophs making TSH; and lactotrophs secreting prolactin. Homeostasis is maintained by adjusting hormone expression and release from the cells of the pituitary and by varying the size of the populations of cells producing each hormone.

The control of the size of the populations of cells within the pituitary is thus critical to maintain endocrine homeostasis, and when cell proliferation becomes uncontrolled, tumours develop. Pituitary adenomas are surprisingly common with an estimated prevalence of 17\% (Ezzat et al. 2004). The proliferation of tumours differs from the physiological expansion in cell populations in that tumours are thought to be monoclonal. However, the distinction between these two processes is not always clear, and some pituitary microadenomas have been observed to be transient, spontaneously resolving, indicating the maintenance of at least some control of the population size. Furthermore, malignant transformation in these tumours is extremely uncommon, showing that they do not behave like adenomas in other tissues (Levy \& Lightman 2003).

In the fetus, the anterior pituitary develops from an invagination of the oral ectoderm which forms Rathke's pouch. Rathke's pouch later forms the anterior pituitary, making contact with the diencephalon which later becomes the posterior pituitary. During development, multipotent cells differentiate into the five hormoneproducing cells of the anterior pituitary.

Wnt signalling is important both for the differentiation of pluripotent cells and in the proliferation of mature cells. This review covers the role that Wnt signalling plays in the development of the anterior pituitary and potential roles in tumorigenesis and plasticity in the adult gland.

\section{Wnt signalling}

Wnt proteins are cell-signalling molecules. Their main effects are to stimulate cell proliferation, differentiation and migration. Wnt1, initially called integration 1 (Int-1)

Published by Bioscientifica Ltd. 
was identified in murine virally induced breast cancers. It was later found to be homologous with the wingless gene, which in Drosophila controls segment polarity. The combination of the terms wingless and integration gave rise to the name 'Wnt'. Nineteen $W n t$ genes are coded by most mammalian (including the human) genomes. Wnt proteins interact with frizzled (Fz) and other co-receptors, for example lipid-related peptide 5/6 (LRP5/6), to form heterodimeric receptors for Wnt proteins. There are thus multiple permutations of Wnts, Fzs and other co-receptors, which can exert multiple effects upon cell activity (Kestler \& Kühl 2008, Clevers \& Nusse 2012).

The intracellular signalling pathways of Wnts are becoming better understood. Three principal mechanisms are currently known: the 'canonical' ( $\beta$-catenin), the 'calcium' and the 'planar cell polarity' pathways (Clevers $\&$ Nusse 2012, Nusse 2012). The specificity of the pathway triggered appears to be dependent upon the Wnt and Fz co-receptor combination, the cell type and the environment of the cell. Furthermore, these pathways may be simultaneously interacting with one another in a 'Wnt signalling network' (Kestler \& Kühl 2008).

$\beta$-Catenin signalling manipulates cell activity by interacting with the T-cell factor (TCF)/lymphocyteenhancing factor (LEF) group of transcription factors. TCFs contain a single high motility group (HMG) domain sufficient for DNA binding and an N-terminal $\beta$-cateninbinding domain. The isoforms TCF1, TCF3 and TCF4 and LEF1 all demonstrate the conservation of an HMG, and in the pituitary demonstrate specific temporal and spatial expression. The binding of $\beta$-catenin to TCF/LEFs results in the activation or de-repression of Wnt target genes (Yi et al. 2011, Archbold et al. 2012, Wu et al. 2012). In an unactivated state, cytoplasmic $\beta$-catenin is bound to adenomatous polyposis coli (APC), axin and glycogen synthase kinase $3 \beta$ (GSK3 $\beta$ ), resulting in the phosphorylation of $\beta$-catenin and its ubiquitination and breakdown. Canonical Wnt signalling is activated when a Wnt ligand binds to an Fz receptor. This causes the binding of APC and axin to this membrane complex and prevents the breakdown of $\beta$-catenin, thus allowing it to accumulate and translocate to the nucleus where it binds TCFs (Clevers \& Nusse 2012, Nusse 2012).

The binding of Wnts to Fz receptors can also trigger the intracellular release of calcium, activating calcium sensitive enzymes such as protein kinase C (PKC), calcium-calmodulin-dependent kinase II (Kremenevskaja et al. 2005), and calcium-sensitive phosphatase calcineurin which subsequently activates the transcription factor NF-AT (Kestler \& Kühl 2008).
The Wnt/planar cell polarity pathway involves the activation of GTPases that activate downstream targets including JNK or rho kinase. This signalling pathway is associated with transmembrane proteins and reconfiguration of the cytoskeleton, thus allowing epithelial cells to set up planar cell polarity (Kestler \& Kühl 2008).

\section{The role of Wnt in pituitary development}

Gene expression for 12 of the Wnt proteins has been identified in the developing pituitary: Wnts $2 b, 3$, $4,5 a, 5 b, 6,7 a, 7 b, 10 a, 11,15$ and 16 (Treier et al. 1998, Olson et al. 2006, Potok et al. 2008). Of these, the investigation so far has focused on Wnt4 and Wnt5a (Treier et al. 1998, Potok et al. 2008). Wnt signalling pathways control the expression of transcription factors that control cell differentiation. We will explore the factors controlled by Wnt signalling before looking at Wnt expression.

Homeodomain transcription factors The homeodomain-containing group of transcription factors are characterised by the presence of a helix-turn-helix DNA-binding domain that enables the factors to drive the transcription of target genes. The differentiation of mature cells from the progenitors of Rathke's pouch relies upon the sequential switching on and off of homeodomain transcription factors.

The generation of the somatotroph, lactotroph and thyrotroph cell lines is dependent on the expression of the transcription factor Pit1 (also known as Pou1f1; Li et al. 1990). Pit1 expression is thought to be stimulated by the paired-like homeodomain transcription factor 'prophet of pit1' (Prop1) and suppressed by Hesx 1 that recruits co-repressors Groucho/TLE and N-CoR (Dasen et al. 2001, Olson et al. 2006). Pitx1 and Pitx2 are expressed in Rathke's pouch and throughout the proliferation and differentiation of all the five populations of hormone-producing cells of the anterior pituitary. Pitx2 is essential for the proliferation of the cells of Rathke's pouch, with its inactivation resulting in severe pituitary hypoplasia (Gage et al. 1999). Pit $x 1^{-1-}$ mice have demonstrated normal formation of Rathke's pouch but defects in hind limb and cleft formation. An overlapping and compensatory role has been suggested between Pitx1 and Pitx2 (Suh et al. 2002). The carefully timed expression of different factors in the cells of Rathke's pouch allows the maintenance of pluripotency and the subsequent differentiation of mature endocrine cells.

Published by Bioscientifica Ltd. 
Pit1 Pit1 expression is dependent upon an interaction between PROP1 and $\beta$-catenin. This complex including Prop1 and $\beta$-catenin also acts in an inhibitory manner to Hes $x 1$ (which itself would suppress Pit1). Transgenic mice expressing a mutant $\beta$-catenin in cells expressing Pitx1 (pituitary precursors) fail to express Pit1 or develop cells expressing GH, TSH $\beta$ or PRL (Olson et al. 2006). This process is independent of TCF and LEF, factors traditionally thought to be the prime target for $\beta$-catenin activity. In Lef1-deficient mice, Pit1 expression along with the number of $\mathrm{GH}$ - and TSH $\beta$-expressing cells was not reduced. Lef1 was found to be present on the evolutionary conserved early enhancer of Pit1. However, two-step chromatin precipitation, pulling down firstly acetylated H3K9, and then Prop1 or Lef1 from the Pit1 enhancer, revealed Prop1 but not Lef1 to be present on the activated early enhancer promoter region of Pit1 at embryonic day 14.5 (e14.5) (Olson et al. 2006). Furthermore, in vitro, in the GHFT-1 pituitary cell line, LEF1 reduced the activity of a Pit1-driven luciferase reporter under the stimulation of $\beta$-catenin and Prop1, suggesting that its effect might be predominantly repressive of Pit1 expression (Olson et al. 2006). Tcf4-deficient mice develop larger anterior pituitaries that are none the less fully differentiated, indicating that Pit1 must be functioning in its absence (Brinkmeier et al. 2003). Tcf3 is required in the developing murine forebrain and dorsal aspect of Rathke's pouch, where it prevents the expression of $\beta$-catenin targets. As there is an interaction between $T c f 3$ and Hesx 1 and as the inhibition of canonical signalling rescues Hesx 1 mutants, it is tempting to postulate that $T c f 3$ could repress Pit1 expression. However, Tcf3 expression is temporally and spatially different from that of Pit1 (Olson et al. 2006, Brinkmeier et al. 2007, Andoniadou et al. 2011), and therefore the possible effects of TCF3-Pit1 interaction remain unproven at present.

Tcf4 Tcf4 regulates the recruitment of cells from the ectoderm to Rathke's pouch and also the rate of cell proliferation within the newly formed pituitary. This process is dependent upon an up-regulation of fibroblast growth factor $10(F g f 10)$ and bone morphogenic protein $(\mathrm{Bmp})$ expression within the developing pituitary by Tcf4. Despite Tcf4 stimulating proliferation and migration, in experiments in mice, the role for $\beta$-catenin in activating this process was not demonstrated, thus the mechanisms responsible for Tcf4 expression have yet to be elucidated (Brinkmeier et al. 2007).
Pitx2 Pitx2 expression is responsible for the proliferation of distinct areas of the embryo, for example the cardiac outflow tract and the anterior pituitary. In e9.75 mice, injection of $\mathrm{LiCl}$, which stimulates canonical Wnt signalling by inhibiting GSK3 $\beta$, caused the displacement of histone deacetylase 1 (HDAC1) from the Lef1 promoter of Pitx2, increasing its expression. A similar response was seen in the aT3-1 pituitary cell line in which a constituently active form of $\beta$-catenin was expressed. The absence of Pitx 2 causes the arrest of pituitary growth by e10.5. This seems to be as a result of growth arrest as the BrdU labelling of e10.5 Pitx $2^{-/-}$pituitaries was reduced by around $65 \%$ compared with controls. The overexpression of Pitx 2 under the control of the Pit1 promoter results in hyperplastic pituitaries with a twofold increase in the number of somatotrophs. This suggests that canonical signalling plays a role in the proliferation of either pituitary progenitors or mature pituitary endocrine cells (Kioussi et al. 2002). The effects of Pitx2 are cell and/or environment specific, as they were, for example, not observed in vitro in the Rat1 cell line which would not normally express Pitx2. In the aT3-1 pituitary cell line, which does express Pitx2, silencing its effects with either siRNA or IgG reduced proliferation. LiCl treatment of the aT3-1 cell line resulted in the recruitment of Pitx 2 and the displacement of Hdac1 from the promoter of cyclin D2 (Kioussi et al. 2002). Despite the fact that there is clearly a role for canonical signalling in inducing Pitx2, the Wnt ligand (if indeed it is a Wnt) responsible has yet to be identified: in non-functioning pituitary adenomas excised from humans, increased PITX2 has been demonstrated. No Wnt proteins were identified in these tumours, but a ninefold increase in secreted Fz-related peptide (sFRP) expression was observed. sFRP is usually associated with the inhibition of canonical signalling; however, it has been shown to have stimulatory effects in certain contexts (Moreno et al. 2005).

Hesx1 In mice in which degradation-resistant $\beta$-catenin was expressed in committed Pit1 lineage cells, development of the differentiated populations was normal (Olson et al. 2006, Gaston-Massuet et al. 2011). However, where degradation-resistant $\beta$-catenin was expressed in Hes $x 1$-expressing cells, there was a reduction in $\mathrm{GH}$ production (Gaston-Massuet et al. 2011). The normal development of the pituitary is thus dependent upon canonical signalling being activated at specific time points. The expression of these factors in the context of the developing murine pituitary is shown diagrammatically in Fig. 1.

Published by Bioscientifica Ltd. 

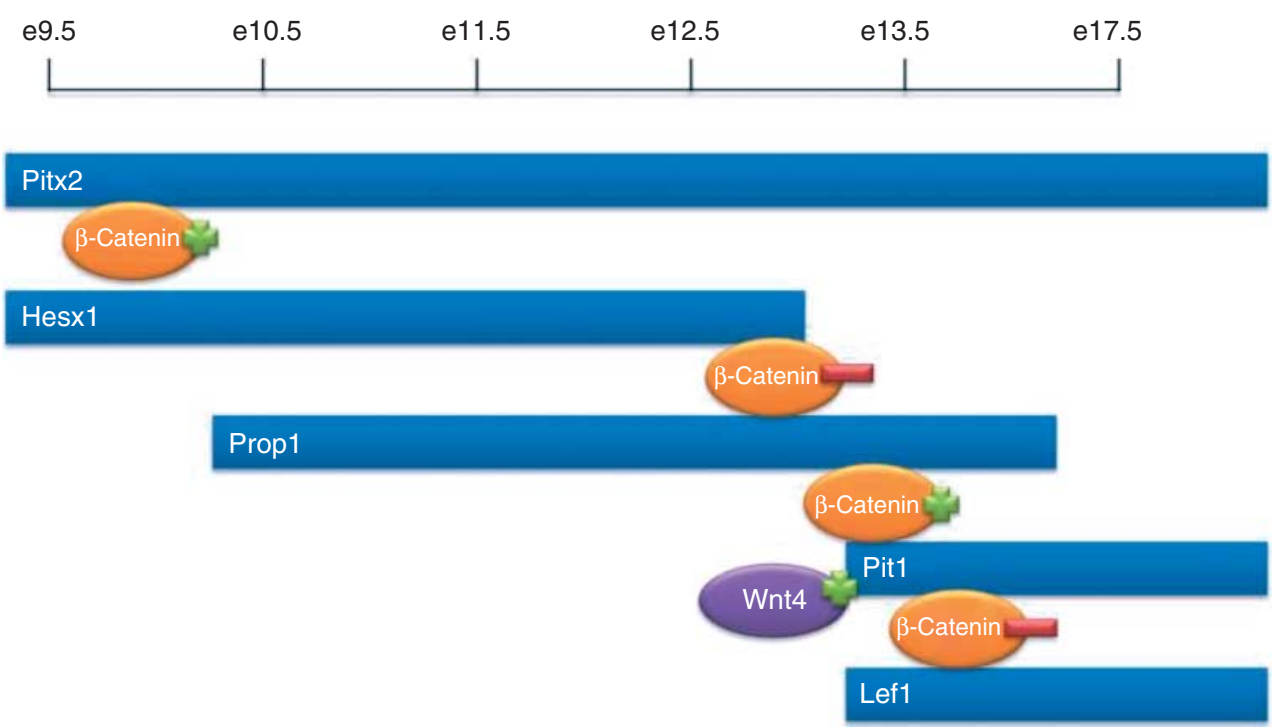

\section{Figure 1}

Summary of the interactions between homeodomain transcription factors and the elements of Wnt signalling important for murine pituitary genesis. The blue boxes represent the expression of transcription factors within Rathke's pouch and the developing pituitary. Manipulation of transcription factor expression by canonical signalling is demonstrated by the orange

Wnt4 Wnt4 is expressed in Rathke's pouch. Wnt4deficient mice have smaller pituitaries and, in particular, reduced populations of cells expressing $\mathrm{GH}, \mathrm{TSH} \beta$ and the $\alpha$-glycoprotein hormone subunit (CgA or POMC), but normal populations of cells expressing Pomc (Treier et al. 1998, Potok et al. 2008). Wnt4 mutant mice also have fewer Pit1-expressing cells, suggesting a reduction in hormone-producing cell precursors and not simply the failure of the cells to proliferate. In these cells, $\beta$-catenin expression, immunoreactivity for Tcf 4 and levels of Lef1 mRNA were undisturbed, suggesting a non-canonical mechanism to be responsible (Potok et al. 2008).

Wnt5a Wnt5a expression is abundant in the diencephalon. In mice, Wnt5a deficiency results in altered morphology of the pituitary, although all the principal hormone-producing cell types still develop. This altered morphology does not appear to be reliant on changes to proliferation rates or to apoptosis and maybe related to cell-cell adhesion (Cha et al. 2004). The expression domain of $W n t 5 a$ in the developing murine pituitary correlates neatly with that of BMP, giving rise to the question as to whether the two signalling systems are linked (Treier et al. 1998, Potok et al. 2008). Wnt5a mutant embryos have demonstrated reduced spatial control of $F g f 10$ expression and the activation of $B M P$, indicating ovals. Direct involvement of the Wnt4 ligand is indicated by the purple oval. Up-regulation of transcription is indicated by the green plus signs; repression is indicated by the red minus signs. $\beta$-Catenin when acting as a co-factor is indicated by an oval positioned between two transcription factors. Time points, in embryonic mice, are indicated along the timeline.

that it may have a regulatory function. There was no change in $\beta$-catenin expression or evidence of the activation of canonical signalling in these mutants, perhaps suggesting a non-canonical mode of action (Potok et al. 2008). In Rathke's pouch explant studies from e9.5 to 10.5 murine embryos, co-expression of both Wnt5a and Bmp4 consistently induced the genesis of hormone-producing cells. However, not all mature cell types were consistently cultured in this model, for example cells expressing GH were much more abundant than cells expressing TSH $\beta$ (Treier et al. 1998).

Wnt6 Wnt6 is expressed around the developing pituitary, but appears not to be essential for cell differentiation or proliferation. Wnt6 mutant mice exhibit no pituitary morphological changes or altered differentiation. Wnt6 was not identified in Rathke's pouch by in situ hybridisation by Potok et al., but mRNA was identified by qPCR of microdissected Rathke's pouch at e12.5 by Olson et al. (2006).

Sox2 Sox 2 is a member of the Sox family of transcription factors that have critical roles in embryonic development. In the human embryonic kidney 293 (HEK293) cell line, the co-transfection model Sox 2 has been shown to inhibit canonical signalling, reducing the readout from a $\beta$-catenin expression plasmid, TOPflash, that consists of

Published by Bioscientifica Ltd 
four TCF-binding sites driving a luciferase reporter. Mutation of Sox2 has been associated with bilateral anophthalmia and hypopituitarism in humans. It has thus been proposed that reduced Sox 2 expression and thus increased canonical signalling might be responsible for this failure in pituitary development (Kelberman et al. 2008). Sox 2 haploinsufficiency has been associated in two cases of non-progressive pituitary tumours of early onset, implicating a possible role for canonical signalling in their formation (Alatzoglou et al. 2011).

\section{Wnts in mature pituitary cells}

In this section, we will explore the role of Wnt signalling in the proliferation and activity of mature pituitary cells. It should be noted that most studies have been conducted on immortalised cell lines that may have altered signalling pathways and thus different characteristics to primary cells or in vivo models.

\section{Lactotrophs}

Oestrogen stimulates the proliferation of lactotrophs. An array study comparing genes expressed in the pituitaries of Fischer 344 rats treated with oestradiol $\left(\mathrm{E}_{2}\right)$ or placebo indicated an increase in the expression of Wnt4, Wnt10a and Wnt inhibitory factor 1 (Wif1). In the GH3 somatolactotroph cell line, $\mathrm{E}_{2}$ was also shown to induce Wnt4 expression. Despite increasing the expression of $W n t 4, \mathrm{E}_{2}$ treatment did not stimulate canonical signalling in these cells; there was no change in the Tcf4 readout from the TOPflash luciferase reporter or the nuclear accumulation of $\beta$-catenin following stimulation by $\mathrm{LiCl}$. GH3 cells are known to demonstrate spontaneous oscillations in intracellular calcium concentrations. Interestingly, Wnt4 was shown to inhibit these calcium oscillations in $63 \%$ of the cells. This effect was lost when GH3 cells were treated with antibodies to immunoneutralise the effect of Wnt4. In addition, $63 \%$ of the cells were shown to be in the G1 phase of the growth cycle, suggesting a possible role for Wnt4 in controlling the cell cycle in these cells. This indicates that Wnts may be acting in a non-canonical manner in these mature pituitary cells (Giles et al. 2011). Furthermore, in mutant mice in which degradationresistant $\beta$-catenin is expressed in lactotrophs, there is no increase in prolactinomas or tumour formation, indicating that canonical signalling does not stimulate growth in these cells (Gaston-Massuet et al. 2011).

$\mathrm{E}_{2}$ increases the expression of Wnt4 in the mature pituitary, which is most convincing in rat primary pituitary cultures where somatotrophs show the most striking response. This increase in Wnt4 expression was not consistently shown in lactotrophs, cells which normally show increased proliferation in response to $\mathrm{E}_{2}$ (Miyakoshi et al. 2009, Giles et al. 2011). In the MtT/S somatotroph cell line, $\mathrm{E}_{2}$ induced Wnt 4 expression. As these cells do not express oestrogen receptor $\beta$ (ER $\beta / E s r 2)$, the mechanism must either be via oestrogen receptor $\alpha$ $(E R \alpha / E s r 1)$ or via a non-classical oestrogen signalling pathway (Miyakoshi et al. 2009). In neuronal primary cultures, $\mathrm{E}_{2}$ treatment activated canonical signalling via an $E R \alpha$ - and $E R \beta$-dependent but non-classical mechanism that resulted in the inactivation of GSK3 $\beta$. Here, oestrogen induced different Wnt target genes than Wnt3a (Varea et al. 2009). Other examples of the endocrine activation of canonical Wnt signalling are discussed below.

\section{Gonadotrophs}

$\beta$-Catenin signalling has been investigated in the gonadotroph cell line L $\beta$ T2. Here, it was shown that GnRH stimulated canonical signalling by inducing the nuclear accumulation of $\beta$-catenin and activating the TCF/LEFdependent transcriptional activity. In HEK293 cells transfected with the GnRH receptor type I, GnRH acted by inducing the phosphorylation of GSK3 $\beta$ at serine 9, as would be expected in canonical signalling. Interestingly, in the L $\beta$ T2 cell line, the phosphorylation of GSK3 $\beta$ was not shown, indicating that GnRH had an effect upon canonical signalling in an alternative manner. This demonstrates that canonical signalling can be stimulated by non-Wnt proteins, and also by the cell specificity of the signalling pathway (Gardner et al. 2007). GnRH induces $L h \beta$ expression in the $\mathrm{L} \beta 2 \mathrm{~T}$ cell line. This too appears to depend upon canonical signalling as $\beta$-catenin binds to $S F-1$ (or Nr5a1, a transcription factor for $L h \beta$ ), leading to increased expression. This shows another mechanism by which $\beta$-catenin affects transcription by interacting with factors other than LEF and TCF and in response to a non-Wnt ligand (Salisbury et al. 2007).

\section{Somatotrophs}

Hesx1-Cre/degradation-resistant $\beta$-catenin mutant mice $\left(\right.$ Hes $\times 1^{\text {Cre/+}} ;$ Ctnnb1 $\left.1^{\text {lox(ex3)/+}}\right)$ exhibit a reduction in the number of cells expressing GH (Gaston-Massuet et al. 2011). Pitx1-expressing cells (Pit1 precursors) in which $\beta$-catenin is conditionally knocked out have also demonstrated reduced numbers of mature somatotrophs (Olson et al. 2006). However, where degradation-resistant

Published by Bioscientifica Ltd. 
$\beta$-catenin was expressed in mature cells expressing GH in Cre-lox mice, there was no sign of any increase in the prevalence of pituitary adenomas or proliferation, indicating a loss of the response to $\beta$-catenin following maturation (Gaston-Massuet et al. 2011). Somatolactotroph cells lines and primary cultures from rat pituitaries express Wnt4 (Miyakoshi et al. 2009, Giles et al. 2011), although there is no literature thus far with respect to a role for Wnt4 signalling in these mature GH-producing cells.

\section{Corticotrophs}

Corticotrophin-releasing hormone has been shown to stimulate an increase in $\beta$-catenin expression in the AtT-20 corticotroph cell line. This appears to be via a mechanism involving the CAMP/PKA pathway, as this effect was lost when inhibitors were used alongside stimuli. Somatotropin release-inhibiting factor (Srif/Sst), an inhibitor of Acth (or Pomc) expression, had the opposite effect and appeared to increase the phosphorylation of $\beta$-catenin. A dominant negative $T c f 4$ vector reduced cell proliferation in this cell line. Thus, it appears that canonical signalling may be active in AtT-20 cells and may be in part responsible for cell cycle regulation. The study did not investigate whether there was any effect by canonical signalling upon Acth expression. Interestingly, these effects were not reproducible in GH3 cells (Khattak et al. 2010). In studies of pituitary development, the canonical pathway has negligible effects upon corticotrophs (Treier et al. 1998, Potok et al. 2008).

\section{Thyrotrophs}

Normal thyrotrophs, corticotrophs, lactotrophs and gonadotrophs have all been shown to express Wnt4 (Giles et al. 2011). Triiodothyronine $\left(\mathrm{T}_{3}\right)$ treatment of TtT-97 thyrotroph tumour cells (which negatively feeds back on TSH production and inhibits growth) resulted in the reduced expression of Wnt1Oa and Bmp4 along with reduced intranuclear $\beta$-catenin and cyclin $\mathrm{A}$ expression. $\mathrm{T}_{3}$ was also shown to impede the readout from the super-TOPflash transcription vector, which has eight TCF-binding elements upstream of a luciferase reporter, suggesting the reduced activation of canonical signalling in these cells. $\mathrm{T}_{3}$ did not alter Pitx 2 or cyclin D1 expression but did reduce cyclin A2 and cyclin B1, indicating a possible mechanism for canonical signalling in controlling cell cycle progression in this model. Thus, there may be a role for canonical Wnt signalling in the proliferation of mature thyrotrophs (Kerr et al. 2005).

\section{Wnt signalling in pituitary tumours}

The study of patients with syndromes resulting in hypopituitarism suggests a potential role for $\beta$-catenin and Wnt signalling.

\section{Multiple endocrine neoplasia type 1}

In a mouse model of multiple endocrine neoplasia type 1 (MEN1), in which patients develop tumours of the anterior pituitary, pancreas and parathyroids, mice developed tumours of the ovary and testes. In these tumours, there was a down-regulation of Wnt4, Wnt9a, Fz6/Fzd6 and Lrp2, although in this study, pituitary tumours were not specifically examined (Mould et al. 2009).

\section{Carney complex}

Carney complex is a MEN syndrome in which there is an increase in the development of tumours, in particular skin tumours, myxomas, schwannomas and endocrine neoplasms. Carney complex occurs due to a mutation resulting in the decreased activity of the gene Prkar1a that codes a regulatory subunit of PKA. There is thus an increase in PKA and cAMP signalling. In the mouse Prkar1a $a^{+/-}$model, tumour formation was less frequent than seen in humans. By crossing these mice with mice in which the tumour-suppressor gene $p 53$ (or Tp53) was knocked down, the phenotype of mice better mirrored that which was expected and developed both thyroid and pituitary tumours of the pars intermedia. The analysis of these mice showed that there was an increased expression of Wnt3, Wnt3a, $\beta$-catenin and Lrp5 mRNA. Furthermore, in an adrenal cell line bearing an inactivating mutation of Prkar1a, cell growth was arrested at the G0/1 phase by inhibiting Wnt 3 expression. Owing to the effect that PRKAR1a has upon PKA, it is possible that Wnt may inhibit growth by interacting with cAMP signalling (Almeida et al. 2010).

\section{ANE syndrome}

In the alopecia, neurological defects and endocrinopathy (ANE) syndrome, patients developed combined anterior hormone deficiency including gonadotrophs and corticotrophs (Spiegel et al. 2010). Skin biopsies taken from one patient with ANE demonstrated a loss of mature follicles and the presence of dermal cysts, mirroring the findings in the skin of mice with $\beta$-catenin deficiency. A reduction in $\beta$-catenin expression in this skin biopsy was also observed,

Published by Bioscientifica Ltd 
indicating that canonical signalling may play a role in the pituitary failure of these patients (Nousbeck et al. 2008, Spiegel et al. 2010).

\section{Wnt1 $^{-1-}$ mice}

In the Wnt1 transgenic mouse model for oestrogen- and progesterone-responsive breast cancer, a loss of the tumour-suppressor gene $p 27$ (or $C d k n 1 b$ ) led to an increase in pituitary, gastric and duodenal tumours (Glover et al. 2009). However, $p 27$ is known to affect pituitary cell proliferation, and thus this finding might be independent of Wnt signalling (Nakayama et al. 1996), especially as Wnt1 was not shown to be expressed in the developing pituitary (Olson et al. 2006).

\section{Human pituitary adenomas}

In pituitary adenomas, Miyakoshi et al. have demonstrated an increased expression of WNT4 and FZ6 in tumours expressing GH, PRL and TSHB, but not in those expressing ACTH when compared with normal human pituitaries. In these tumours, there was no change in $\beta$-catenin distribution; thus, it appears that when Wnt acts, it exerts its effects in a non-canonical manner. The phosphorylation of CaMK-II, an indicator of calcium signalling, was no different in these tumours when compared with normal tissue, although the levels were raised in two ACTHomas and one gonadotrophinoma. C-jun, a target of the planar cell polarity pathway, was inconsistently observed in some of the adenomas but not in the normal pituitary tissue. Thus, there is evidence that WNT4 may play a role in the development of some adenomas, especially those of cells from the Pit1 lineage; however, there is little evidence to suggest what mechanism might be employed (Miyakoshi et al. 2008). There is also inconsistency between studies of pituitary adenomas. In one study investigating $\beta$-catenin expression, nuclear accumulation of $\beta$-catenin was found in $57 \%$ of tumours; however, it did not compare this finding with healthy pituitary tissue. In this study, the expression was especially high in the tumours of cells from the Pit1 lineage (Semba et al. 2001). In a study of 47 pituitary adenomas, Formosa et al. found no changes in $\beta$-catenin expression, but did find increased immunostaining for the Wnt target genes cyclin D1 and $c-M y c$ (or MYC). Cyclin D1 was associated with a later age of presentation, whereas MYC was seen in younger patients. These markers demonstrated little correlation with tumour size, although patients with hypopituitarism demonstrated a reduction in $M Y C$ expression. Interestingly, cyclin D1 was observed to be more abundant in male than female patients, indicating a possible endocrine stimulation for its expression. These results perhaps suggest a $\beta$-cateninindependent mechanism to be activated in these tumours (Formosa et al. 2012). In the $\alpha \mathrm{T} 3-1$ gonadotroph tumour cell line, transfection with a dominant-negative PITX2 and PITX2 siRNA resulted in a gross reduction in cell viability by increasing apoptosis. This effect was replicated in primary cultures from five out of seven human gonadotroph adenomas. Given that PITX2 is under the control of $\beta$-catenin, canonical signalling may be implicated in the pathogenesis of these tumours (Acunzo et al. 2011). Clearly, further work is warranted to clarify the activation of Wnt signalling in pituitary tumours and identify the pathway(s) involved.

sFRP acts as an inhibitor of the Fz co-receptor complex. The sFRP 'WIF1' inhibits Wnt signalling and has been shown to be down-regulated in a series of both functioning and non-functioning pituitary adenomas when compared with healthy pituitary tissue. This finding on a microarray was verified by qPCR and was associated with the methylation of the $\mathrm{CpG}$ island on the promoter of WIF1, demonstrating the potential epigenetic regulation of Wnt signalling. This finding was also demonstrated in vitro in the GH3 cell line, which demonstrated little WIF1 expression but in which the transfection of WIF1 resulted in reduced proliferation. No changes in $\beta$-catenin localisation were observed in this study of 42 pituitary adenomas (Elston et al. 2008).

\section{Wilms tumours}

WNT4 is regulated by Wilms tumour 1 (WT1) in paediatric nephroblastomas. It was postulated that WT1 might also play a role in pituitary adenoma formation. In a series of 90 pituitary tumours, no evidence was found to support the role of WT1 in tumorigenesis (Schittenhelm et al. 2009).

In summary, there is clear evidence that the expression of Wnt signalling molecules is altered in pituitary adenomas. The precise mechanisms underlying these changes and their causality still require further interrogation in order to form a clear overall view of the likely significance of these signalling pathways in pituitary tumorigenesis.

\section{Wnt and craniopharyngiomas}

A craniopharyngioma is a benign epithelial tumour arising from around the sella turcica and represents $3 \%$ of all

Published by Bioscientifica Ltd 
intracranial tumours. In the adamantinomatous subtype of craniopharyngiomas, there is good evidence that canonical signalling is important in tumorigenesis. Nuclear $\beta$-catenin has been demonstrated in several studies of these tumours in humans, including seven of nine tumours (Hassanein et al. 2003) and ten of ten tumours (Sekine et al. 2002). In the latter study, missense mutations were observed in the site at which GSK3 $\beta$ phosphorylates $\beta$-catenin, indicating that activated canonical signalling may play a role in tumorigenesis and/or proliferation. Furthermore, in a series of 16 patients treated surgically for craniopharyngioma, eight of them exhibited mutations of $\beta$-catenin, six of which were in children. Of note, in these tumours, there were no mutations found in HESX1, PROP1 or PIT1, although the study did not explore quantitative changes in the expression of these transcription factors which, under the control of canonical signalling, regulate differentiation (Campanini et al. 2010). In another study of 14 adamantinomatous craniopharyngiomas, heterozygous mutations in $\beta$-catenin were found in nine patients in regions that would affect the phosphorylation of $\beta$-catenin by GSK3 $\beta$. All 14 patients demonstrated the accumulation of nuclear $\beta$-catenin (Cani et al. 2011).

Hes $\times 1^{\text {Cre/+ }}$;Ctnnb ${ }^{\text {lox(ex3)/+ }}$ mutant mice develop large cystic pituitary tumours that were both histologically and immunohistologically similar to human adamantinomatous craniopharyngiomas. Interestingly, canonical signalling appeared to be activated in islands of cells in these pituitaries that did not express hormones, nor did they stain with Ki67 or incorporate BrdU, suggesting that canonical signalling may be activated in cells that were not themselves replicating. Thus, it may be that these are tumour precursor cells or that they stimulate the growth of other cells in the pituitary. These cells may support evidence that populations of stem cells are present within the pituitary (Gaston-Massuet et al. 2011). Triple heterozygous Hesx $1^{\mathrm{Cre} /+}$; Ctnnb $1^{\text {lox(ex3)/++}}$; BAT-gal mice express $\beta$-galactosidase in cells with nucleocytoplasmic (as opposed to membranous) $\beta$-catenin ( $\beta$-catenin ${ }^{\text {nc }}$ ) allowed these cells to be separated by flow cytometry. $\beta$-Catenin ${ }^{\text {nc }}$ cells expressed reduced levels of terminal differentiation markers such as Pit1, GH and POMC. Although more of these cells were capable of forming colonies than cells with membrane-bound $\beta$-catenin, only $5 \%$ of them were actually capable of forming colonies and thus stemness in these cells is likely to be related to another factor, for example Sox 2 expression. The separated $\beta$-catenin ${ }^{\mathrm{nc}}$ cells expressed increased expression of the members of the BMP and FGF families of signalling molecules, which, as we have seen, are essential for normal pituitary development, perhaps indicating a paracrine role for these cells in the activity of pituitary stem-like cells (Andoniadou et al. 2012). In the $\left(\mathrm{Hes}_{1} 1^{\mathrm{Cre} /+} ; \mathrm{Ctnnb} 1^{\text {lox(ex3)/+}}\right)$ pituitaries, the number of cells producing GH was significantly reduced, resulting in phenotypic dwarf mice. There was no change in the number of ACTH-producing cells, indicating that this effect was constrained to Pit1-derived cells (Gaston-Massuet et al. 2011).

Table 1 A summary of evidence regarding the role played by Wnt dysregulation in human pituitary tumours.

\begin{tabular}{|c|c|c|}
\hline Tumour & Species & Wnt dysregulation \\
\hline $\begin{array}{l}\text { Multiple endocrine neoplasia } \\
\text { type } 1\end{array}$ & Mouse & $\begin{array}{l}\text { Down-regulation of Wnt4, Wnt9a, Fz6 and Lrp2, } \\
\text { but pituitaries not specifically examined }\end{array}$ \\
\hline Carney complex & Mouse & $\begin{array}{l}\text { Prkar1a }{ }^{+1-} p 53^{+1-} \text { mice demonstrate increased } \\
\text { Wnt3, Wnt3a, } \beta \text {-catenin and Lrp5 expression }\end{array}$ \\
\hline $\begin{array}{l}\text { Alopecia, neurological deficits } \\
\text { and endocrinopathy }\end{array}$ & Human & Reduction in dermal $\beta$-catenin \\
\hline $\begin{array}{l}G H-, P R L-\text { and } T S H B \text {-expressing } \\
\text { human pituitary adenomas }\end{array}$ & Human & $\begin{array}{l}\text { Increased WNT4 and FZ6 expression, but no } \\
\text { change in } \beta \text {-catenin }\end{array}$ \\
\hline Pituitary adenomas & Human & $\begin{array}{l}\beta \text {-Catenin nuclear accumulation in } 57 \% \\
\text { (no control) }\end{array}$ \\
\hline Pituitary adenomas & & $\begin{array}{l}\text { Increased cyclin D1 and c-Myc (Wnt target genes) } \\
\text { in later presenting tumours }\end{array}$ \\
\hline Pituitary adenomas & & $\begin{array}{l}\text { Methylation of the WIF1 promoter increased, } \\
\text { resulting in reduced WIF1 expression }\end{array}$ \\
\hline $\begin{array}{l}\text { Adamantinomatous } \\
\text { craniopharyngioma }\end{array}$ & Mouse & $\begin{array}{l}\text { Hes } x 1^{\mathrm{Cre} /+} ; C \operatorname{Ctn} \mathrm{b} 1^{\mathrm{lox}(\mathrm{ex} 3) /+} \text { mice develop cystic } \\
\text { pituitary tumours which mimic adamantino- } \\
\text { matous craniopharyngioma }\end{array}$ \\
\hline Pituitary adenomas & Human & Nuclear $\beta$-catenin accumulation \\
\hline
\end{tabular}

\section{Reference}

Mould et al. (2009)

Almeida et al. (2010)

Nousbeck et al. (2008) and

Spiegel et al. (2010)

Miyakoshi et al. (2008)

Semba et al. (2001)

Formosa et al. (2012)

Elston et al. (2008)

Andoniadou et al. (2011) and Gaston-Massuet et al. (2011)

Sekine et al. (2002), Hassanein et al. (2003), Campanini et al. (2010) and Cani et al. (2011) http://erc.endocrinology-journals.org DOI: 10.1530/ERC-13-0005
(C) 2013 Society for Endocrinology Printed in Great Britain
Published by Bioscientifica Ltd. 
A summary of the effects of Wnt signalling dysregulation in human and murine examples of pituitary tumours can be found in Table 1 .

\section{Concluding remarks}

There is accumulating evidence that Wnt signalling plays a role in pituitary organogenesis. Most compelling is the role that $\beta$-catenin plays in the regulation of transcription factor expression by interacting to form complexes that both stimulate and inhibit gene expression. It is also clear that some of the Wnt proteins themselves play a role in the process as the pituitaries of Wnt4-deficient mice are lacking in the cells of the Pit 1 lineage. What remains to be elucidated is a connection between the Wnt ligand and the intracellular effect. Further work is likely to identify the protein complexes responsible for switching on and off canonical signalling during the development of the pituitary. So far, experimental work has focused on tractable mouse models; however, it will be interesting to see how findings are transferable between species. This is particularly important in the translation to understanding tumours in humans, where pituitary lineage development may have significant differences from that in rodents (Pope et al. 2006).

In adult pituitaries, Wnt signalling plays a role in the activity and proliferation of mature hormone-producing cells. Here, there is building evidence for alternative Wnt signalling pathways being activated, for example Wnt4 affecting calcium oscillations in GH3 cells (Giles et al. 2011). It is also interesting to note that trophic hormones have been found to stimulate canonical signalling in these mature cells (Kerr et al. 2005, Gardner et al. 2007, Khattak et al. 2010). Wnt signalling has been mainly demonstrated in cell lines, which, by their very nature, may have altered proliferative properties, thus it is essential for further in vivo studies to confirm the effects seen in vitro. mRNA expression patterns seem to indicate that Wnt signalling does play a role in in vivo models.

Canonical signalling clearly plays a different role in embryonic and mature cells. For example, activating $\beta$-catenin in differentiated cells had little effect compared with those still to mature (Gaston-Massuet et al. 2011). This altered response may help us improve ideas about pituitary plasticity; as most ex vivo studies of pituitary tumours fail to identify activated canonical signalling, it might indicate a mature as opposed to stem cell origin for these tumours. Further questions lie in changes to the mechanism of Wnt signalling with time; for example, how does a Wnt ligand stimulate canonical signalling in immature cells and then calcium signalling in adults?
The exploration of Wnt signalling in pituitary cells has demonstrated the complexity of the mechanisms involved in maintaining homeostasis. Wnt signalling is clearly important but appears to play only part of a network of signals, balancing cell activity, proliferation and apoptosis. The composition of the pituitary, with its multiple cell types distributed among each other, makes it a complex model in which to study a signalling network; nevertheless, it is this complexity that makes it ideal for us to better understand the interactions responsible for the actions of Wnt molecules.

\section{Declaration of interest}

The authors declare that there is no conflict of interest that could be perceived as prejudicing the impartiality of the review reported.

\section{Funding}

The authors are grateful to the Wellcome Trust for funding that supported this work.

\section{References}

Acunzo J, Roche C, Defilles C, Thirion S, Quentien M-H, Figarella-Branger D, Graillon T, Dufour H, Brue T, Pellegrini I et al. 2011 Inactivation of pitx2 transcription factor induced apoptosis of gonadotroph tumoral cells. Endocrinology 152 3884-3892. (doi:10.1210/en.2011-1216)

Alatzoglou KS, Andoniadou CL, Kelberman D, Buchanan CR, Crolla J, Arriazu MC, Roubicek M, Moncet D, Martinez-Barbera JP \& Dattani MT 2011 Sox2 haploinsufficiency is associated with slow progressing hypothalamo-pituitary tumours. Human Mutation 32 1376-1380. (doi:10.1002/humu.21606)

Almeida MQ, Muchow M, Boikos S, Bauer AJ, Griffin KJ, Tsang KM, Cheadle C, Watkins T, Wen F, Starost MF et al. 2010 Mouse Prkar1a haploinsufficiency leads to an increase in tumors in the Trp53+/- or $\mathrm{Rb} 1+/-$ backgrounds and chemically induced skin papillomas by dysregulation of the cell cycle and wnt signaling. Human Molecular Genetics 19 1387-1398. (doi:10.1093/hmg/ddq014)

Andoniadou CL, Signore M, Young RM, Gaston-Massuet C, Wilson SW, Fuchs E \& Martinez-Barbera JP 2011 HESX1- and TCF3-mediated repression of Wnt/ $\beta$-catenin targets is required for normal development of the anterior forebrain. Development 138 4931-4942. (doi:10.1242/ dev.066597)

Andoniadou CL, Gaston-Massuet C, Reddy R, Schneider RP, Blasco MA, Tissier PL, Jacques TS, Pevny LH, Dattani MT \& Martinez-Barbera JP 2012 Identification of novel pathways involved in the pathogenesis of human adamantinomatous craniopharyngioma. Acta Neuropathologica 124 259-271. (doi:10.1007/s00401-012-0957-9)

Archbold HC, Yang YX, Chen L \& Cadigan KM 2012 How do they do wnt they do?: regulation of transcription by the wnt/ $\beta$-catenin pathway Acta Physiologica 204 74-109. (doi:10.1111/j.1748-1716.2011.02293.x)

Brinkmeier ML, Potok MA, Cha KB, Gridley T, Stifani S, Meeldijk J, Clevers H \& Camper SA 2003 TCF and Groucho-related genes influence pituitary growth and development. Molecular Endocrinology 17 2152-2161. (doi:10.1210/me.2003-0225)

Brinkmeier ML, Potok MA, Davis SW \& Camper SA 2007 TCF4 deficiency expands ventral diencephalon signaling and increases induction 
of pituitary progenitors. Developmental Biology $311396-407$ (doi:10.1016/j.ydbio.2007.08.046)

Campanini ML, Colli LM, Paixao BMC, Cabral TPF, Amaral FC, Machado HR, Neder LS, Saggioro F, Moreira AC, Antonini SRR et al. 2010 CTNNB1 gene mutations, pituitary transcription factors, and microRNA expression involvement in the pathogenesis of adamantinomatous craniopharyngiomas. Hormones \& Cancer 1 187-196. (doi:10.1007/s12672-010-0041-7)

Cani CMG, Matushita H, Carvalho LRS, Soares IC, Brito LP, Almeida MQ \& Mendonça BB 2011 PROP1 and CTNNB1 expression in adamantinomatous craniopharyngiomas with or without $\beta$-catenin mutations. Clinics 66 1849-1854.

Cha KB, Douglas KR, Potok MA, Liang H, Jones SN \& Camper SA 2004 Wnt5a signaling affects pituitary gland shape. Mechanisms of Development 121 183-194. (doi:10.1016/j.mod.2003.12.002)

Clevers H \& Nusse R 2012 Wnt/ $\beta$-catenin signaling and disease. Cell 149 1192-1205. (doi:10.1016/j.cell.2012.05.012)

Dasen JS, Barbera JP, Herman TS, Connell SO, Olson L, Ju B, Tollkuhn J, Baek SH, Rose DW \& Rosenfeld MG 2001 Temporal regulation of a paired-like homeodomain repressor/TLE corepressor complex and a related activator is required for pituitary organogenesis. Genes and Development 15 3193-3207. (doi:10.1101/gad.932601)

Elston MS, Gill AJ, Conaglen JV, Clarkson A, Shaw JM, Law AJJ, Cook RJ, Little NS, Clifton-Bligh RJ, Robinson BG et al. 2008 Wnt pathway inhibitors are strongly down-regulated in pituitary tumors. Endocrinology 149 1235-1242. (doi:10.1210/en.2007-0542)

Ezzat S, Asa SL, Couldwell WT, Barr CE, Dodge WE, Vance ML \& McCutcheon IE 2004 The prevalence of pituitary adenomas: a systematic review. Cancer 101 613-619. (doi:10.1002/cncr.20412)

Formosa R, Gruppetta M, Falzon S, Santillo G, DeGaetano J, XuerebAnastasi A \& Vassallo J 2012 Expression and clinical significance of Wnt players and survivin in pituitary tumours. Endocrine Pathology 23 123-131. (doi:10.1007/s12022-012-9197-8)

Gage PJ, Suh H \& Camper SA 1999 Dosage requirement of Pitx2 for development of multiple organs. Development $1264643-4651$.

Gardner S, Maudsley S, Millar RP \& Pawson AJ 2007 Nuclear stabilization of $\beta$-catenin and inactivation of glycogen synthase kinase- $3 \beta$ by gonadotropin-releasing hormone: targeting wnt signaling in the pituitary gonadotrope. Molecular Endocrinology 21 3028-3038. (doi:10.1210/ me.2007-0268)

Gaston-Massuet C, Andoniadou CL, Signore M, Jayakody SA, Charolidi N, Kyeyune R, Vernay B, Jacques TS, Taketo MM, Le Tissier P et al. 2011 Increased wingless (wnt) signaling in pituitary progenitor/stem cells gives rise to pituitary tumors in mice and humans. PNAS $\mathbf{1 0 8}$ 11482-11487. (doi:10.1073/pnas.1101553108)

Giles A, Madec F, Friedrichsen S, Featherstone K, Chambers T, Harper CV, Resch J, Brabant G \& Davis JRE 2011 Wnt signaling in estrogen-induced lactotroph proliferation. Journal of Cell Science 124 540-547. (doi:10.1242/jcs.078642)

Glover CE, Gurley KE, Kim K-H, Storer B, Fero ML \& Kemp CJ 2009 Endocrine dysfunction in p27kip1 deficient mice and susceptibility to wnt-1 driven breast cancer. Carcinogenesis 30 1058-1063. (doi:10.1093/ carcin/bgp089)

Hassanein AM, Glanz SM, Kessler HP, Eskin TA \& Liu C 2003 -Catenin is expressed aberrantly in tumors expressing shadow cells. pilomatricoma, craniopharyngioma, and calcifying odontogenic cyst. American Journal of Clinical Pathology 120 732-736. (doi:10.1309/ EALEG7LD6W7167PX)

Kelberman D, de Castro SCP, Huang S, Crolla JA, Palmer R, Gregory JW, Taylor D, Cavallo L, Faienza MF, Fischetto R et al. 2008 Sox2 plays a critical role in the pituitary, forebrain, and eye during human embryonic development. Journal of Clinical Endocrinology and Metabolism 93 1865-1873. (doi:10.1210/jc.2007-2337)

Kerr JM, Gordon DF, Woodmansee WW, Sarapura VD, Ridgway EC \& Wood WM 2005 Growth arrest of thyrotropic tumors by thyroid hormone is correlated with novel changes in wnt-10a. Molecular and Cellular Endocrinology 238 57-67. (doi:10.1016/j.mce.2005.03.004)

Kestler HA \& Kühl M 2008 From individual wnt pathways towards a wnt signalling network. Philosophical Transactions of the Royal Society of London. Series B, Biological Sciences 363 1333-1347. (doi:10.1098/rstb.2007.2251)

Khattak MNK, Buchfelder M, Kleindienst A, Schöfl C \& Kremenevskaja N $2010 \mathrm{Crh}$ and srif have opposite effects on the wnt/ $\beta$-catenin signalling pathway through pka/gsk-3 $\beta$ in corticotroph pituitary cells. Cancer Investigation 28 797-805. (doi:10.3109/07357907.2010.494318)

Kioussi C, Briata P, Baek SH, Rose DW, Hamblet NS, Herman T, Ohgi KA, Lin C, Gleiberman A, Wang J et al. 2002 Identification of a wnt/dvl/ $\beta$-catenin $\rightarrow$ pitx2 pathway mediating cell-type-specific proliferation during development. Cell 111 673-685. (doi:10.1016/S0092-8674(02)01084-X)

Kremenevskaja N, von Wasielewski R, Rao AS, Schöfl C, Andersson T \& Brabant G 2005 Wnt-5a has tumor suppressor activity in thyroid carcinoma. Oncogene 24 2144-2154. (doi:10.1038/sj.onc.1208370)

Levy A \& Lightman S 2003 Molecular defects in the pathogenesis of pituitary tumours. Frontiers in Neuroendocrinology 24 94-127. (doi:10.1016/S0091-3022(03)00012-8)

Li S, Crenshaw EB, Rawson EJ, Simmons DM, Swanson LW \& Rosenfeld MG 1990 Dwarf locus mutants lacking three pituitary cell types result from mutations in the pou-domain gene pit-1. Nature 347 528-533. (doi:10.1038/347528a0)

Miyakoshi T, Takei M, Kajiya H, Egashira N, Takekoshi S, Teramoto A \& Osamura RY 2008 Expression of wnt4 in human pituitary adenomas regulates activation of the $\beta$-catenin-independent pathway. Endocrine Pathology 19 261-273. (doi:10.1007/s12022-008-9048-9)

Miyakoshi T, Kajiya H, Miyajima K, Takei M, Tobita M, Takekoshi S \& Osamura RY 2009 The expression of wnt 4 is regulated by estrogen via an estrogen receptor $\alpha$-dependent pathway in rat pituitary growth hormone-producing cells. Acta Histochemica et Cytochemica 42 205-213. (doi:10.1267/ahc.09033)

Moreno CS, Evans C-O, Zhan X, Okor M, Desiderio DM \& Oyesiku NM 2005 Novel molecular signaling and classification of human clinically nonfunctional pituitary adenomas identified by gene expression profiling and proteomic analyses. Cancer Research 65 10214-10222. (doi:10.1158/0008-5472.CAN-05-0884)

Mould AW, Duncan R, Serewko-Auret M, Loffler KA, Biondi C, Gartside M, Kay GF \& Hayward NK 2009 Global expression profiling of sex cord stromal tumors from men 1 heterozygous mice identifies altered TGF- $\beta$ signaling, decreased gata 6 and increased csf1r expression. International Journal of Cancer 124 1122-1132. (doi:10.1002/ijc.24057)

Nakayama K, Ishida N, Shirane M, Inomata A, Inoue T, Shishido N, Horii I, Loh DY \& Nakayama K 1996 Mice lacking p27(kip1) display increased body size, multiple organ hyperplasia, retinal dysplasia, and pituitary tumors. Cell 85 707-720. (doi:10.1016/S0092-8674(00)81237-4)

Nousbeck J, Spiegel R, Ishida-Yamamoto A, Indelman M, Shani-Adir A, Adir N, Lipkin E, Bercovici S, Geiger D, van Steensel MA et al. 2008 Alopecia, neurological defects, and endocrinopathy syndrome caused by decreased expression of rbm28, a nucleolar protein associated with ribosome biogenesis. American Journal of Human Genetics $\mathbf{8 2}$ 1114-1121. (doi:10.1016/j.ajhg.2008.03.014)

Nusse R 2012 Wnt signaling. Cold Spring Harbor Perspectives in Biology 4 a011163. (doi:10.1101/cshperspect.a011163)

Olson LE, Tollkuhn J, Scafoglio C, Krones A, Zhang J, Ohgi KA, Wu W, Taketo MM, Kemler R, Grosschedl R et al. 2006 Homeodomainmediated $\beta$-catenin-dependent switching events dictate cell-lineage determination. Cell 125 593-605. (doi:10.1016/j.cell.2006.02.046)

Pope C, McNeilly JR, Coutts S, Millar M, Anderson RA \& McNeilly AS 2006 Gonadotrope and thyrotrope development in the human and mouse anterior pituitary gland. Developmental Biology 297 172-181. (doi:10.1016/j.ydbio.2006.05.005)

Potok MA, Cha KB, Hunt A, Brinkmeier ML, Leitges M, Kispert A \& Camper SA 2008 Wnt signaling affects gene expression in the ventral diencephalon and pituitary gland growth. Developmental Dynamics 237 1006-1020. (doi:10.1002/dvdy.21511) 
Salisbury TB, Binder AK, Grammer JC \& Nilson JH 2007 Maximal activity of the luteinizing hormone $\beta$-subunit gene requires $\beta$-catenin. Molecular Endocrinology 21 963-971. (doi:10.1210/me.2006-0383)

Schittenhelm J, Psaras T, Honegger J, Trautmann K, Meyermann R \& Beschorner R 2009 No evidence for wt1 involvement in a $\beta$-cateninindependent activation of the wnt signaling pathway in pituitary adenomas. Endocrine Pathology 20 158-162. (doi:10.1007/s12022-009-9078-y)

Sekine S, Shibata T, Kokubu A, Morishita Y, Noguchi M, Nakanishi Y, Sakamoto M \& Hirohashi S 2002 Craniopharyngiomas of adamantinomatous type harbor $\beta$-catenin gene mutations. American Journal of Pathology 161 1997-2001. (doi:10.1016/S0002-9440(10)64477-X)

Semba S, Han SY, Ikeda H \& Horii A 2001 Frequent nuclear accumulation of $\beta$-catenin in pituitary adenoma. Cancer 91 42-48. (doi:10.1002/ 1097-0142(20010101)91:1<42::AID-CNCR6 > 3.0.CO;2-7)

Spiegel R, Shalev SA, Adawi A, Sprecher E \& Tenenbaum-Rakover Y 2010 ANE syndrome caused by mutated RBM28 gene: a novel etiology of combined pituitary hormone deficiency. European Journal of Endocrinology 162 1021-1025. (doi:10.1530/EJE-10-0077)
Suh H, Gage PJ, Drouin J \& Camper SA 2002 Pitx2 is required at multiple stages of pituitary organogenesis: pituitary primordium formation and cell specification. Development 129 329-337.

Treier M, Gleiberman AS, O'Connell SM, Szeto DP, McMahon JA, McMahon AP \& Rosenfeld MG 1998 Multistep signaling requirements for pituitary organogenesis in vivo. Genes and Development 12 1691-1704. (doi:10.1101/gad.12.11.1691)

Varea O, Garrido JJ, Dopazo A, Mendez P, Garcia-Segura LM \& Wandosell F 2009 Estradiol activates $\beta$-catenin dependent transcription in neurons. PLOS ONE 4 e5153. (doi:10.1371/journal.pone.0005153)

Wu C-I, Hoffman JA, Shy BR, Ford EM, Fuchs E, Nguyen H \& Merrill BJ 2012 Function of wnt/ $\beta$-catenin in counteracting tcf3 repression through the tcf3- $\beta$-catenin interaction. Development 139 2118-2129. (doi:10.1242/ dev.076067)

Yi F, Pereira L, Hoffman JA, Shy BR, Yuen CM, Liu DR \& Merrill BJ 2011 Opposing effects of tcf 3 and tcf1 control wnt stimulation of embryonic stem cell self-renewal. Nature Cell Biology 13 762-770. (doi:10.1038/ ncb2283)

Received in final form 15 February 2013

Accepted 4 March 2013

Made available online as an Accepted Preprint

5 March 2013
(C) 2013 Society for Endocrinology Printed in Great Britain
Published by Bioscientifica Ltd. 